\title{
Seminal Cell-Free DNA Test for the Management of Male Infertility
}

\author{
Modou Mamoune Mbaye ${ }^{1}$, Bouchra EI Khalfi ${ }^{1}$, Noureddine Louanjli ${ }^{2}$, \\ Brahim Saadani ${ }^{3}$, Ismail Kaarouch ${ }^{3}$, Aicha Madkour ${ }^{3}$ \\ and Abdelaziz Soukri ${ }^{{ }^{*}}$
}

${ }^{1}$ Physiopathology, Molecular Genetics and Biotechnology Laboratory, Ain Chock Faculty of Science, Biology and Center for Health Research, Hassan II University of Casablanca, Morocco. ${ }^{2}$ Laboratory of Medical Analyzes, Reproductive Biology, Labomac, Casablanca, Morocco.

${ }^{3}$ In vitro Fertilization Center IRIFIV, IRIS Clinic, Casablanca, Morocco.

Authors' contributions

This work was carried out in collaboration among all authors. All authors read and approved the final manuscript.

Article Information

DOI: $10.9734 / A R R B / 2018 /$ v30i530025

Editor(s):

(1) Dr. Manikant Tripathi, Department of Microbiology, Dr. Ram Manohar Lohia Avadh University, India.

(2) Dr. George Perry, Dean and Professor of Biology, University of Texas at San Antonio, USA.

Reviewers:

(1) Valdir Florencio da Veiga Junior, Military Institute of Engineering, Brazil.

(2) Iya Eze Bassey, University of Calabar, Nigeria.

Complete Peer review History: http://www.sdiarticle3.com/review-history/46952

Review Article

Received 18 December 2018

Accepted 07 February 2019

Published 13 March 2019

\section{ABSTRACT}

The use of extracellular or circulating nucleic acids (Cfs), as a diagnostic or prognostic tool in oncology, has been broadly documented. However, their use in gynecology-obstetrics as noninvasive biomarkers in the management of infertility has become a recurring fact. The circulating nucleic acids are constituted by: free DNA which can be long or short DNA strands resulting from the apoptotic or necrotic processes, the free RNA containing: micro-RNAs (miRNAs) which are short single-stranded ribonucleic acids (RNA) that are able to deter the production of protein from a gene, Piwi-interacting RNAs (PiRNAs) that are small RNAs expressed in germ cells or even early embryos and small interfering RNAs (siRNAs) that are small RNAs that can bind specifically to a messenger RNA sequence and prevent gene expression by cleaving that RNA. The presence of circulating nucleic acids in many biological fluids such as: urine, seminal plasma and serum, the fact that they 
are easy to detect, the variation of their level according to the physiopathological conditions of the body and their implication in many biological processes such as folliculogenesis, steroidogenesis and spermatogenesis make nucleic acids circulating important biomarkers of interest in the management of male infertility. They compose a real complementary help for practitioners of medically assisted procreation. As a result, circulating nucleic acids are a promising avenue in the prevention of implantation failures. In this article, we will seek to affirm further, their importance in the management of male infertility, by highlighting their different uses.

Keywords: Circulating nucleic acids; male infertility; spermatogenesis; teratozoospermia; asthenozoospermia and oligozoospermia.

\section{ABBREVIATIONS}

$\begin{array}{ll}\text { Cf } & \text { : Circulating nucleic acid } \\ \text { DNA }: \text { Deoxyribonucleic acid } \\ \text { ART : Assisted reproductive technology } \\ \text { RNA : Ribonucleic acid } \\ \text { mRNA : Messenger RNA } \\ \text { miRNA : MicroRNA } \\ \text { PIRNAs: Interaction of RNA with piwi } \\ \text { SiRNA : Small interfering RNA } \\ \text { OA : Obstructive Azoospermia } \\ \text { NOA : Non Obstructive Azoospermia } \\ \text { ROS : Reactive oxygen species } \\ \text { DFI : Fragmentation of DNA } \\ \text { MEST : Mesoderm-Specific Transcriptase } \\ \text { PTGDS: Prostaglandin-D-Synthase }\end{array}$

\section{INTRODUCTION}

Interest in extracellular or circulating nucleic acids as biomarkers of interest in obstetric gynecology is well established. Circulating nucleic acids are used as potential biomarkers in the management of human infertility. Because they are easily detectable in many biological fluids [1], their rate varies depending on the physiopathological conditions of the body [2] and their involvement in many biological processes: steroidogenesis [3], spermatogenesis [4]. They are commonly used in the management of female infertility as a non-invasive biomarker in the detection and / or monitoring of pathologies of pregnancy [5], fetal and / or embryonic abnormalities [6] and finally in the evaluation of the functional state of the ovary [7]. Thus nucleic acids offer new perspectives, both from an innovative diagnostic and prognostic point of view in the management of human infertility. In this article we will not only explore the different components of circulating nucleic acids but also show the different uses of these in medically assisted procreation (PMA).

\section{THE CIRCULATION OF NUCLEIC ACIDS OR EXTRACELLULAR IN BIOLOGICAL FLUIDS}

Circulation of nucleic acids plays an important role in human pathophysiology. New data in the essay suggests that circulating nucleic acids plays a vital role in the management of male infertility [8].

\subsection{Circulation of Nucleic Acids (CfDNAs and CfRNAs)}

Circulation of nucleic acids consists of free DNA and free RNA which consists of: messenger ribonucleic acid (mRNA) and three large noncoding RNAs: microRNA (miRNA), Piwiinteracting RNA (PiRNA), small interfering RNAs (siRNA) [9]. The rate of nucleic acids varies according to pathophysiological conditions [10]. This variation reflects the physiopathological conditions and explains the use of nucleic acids as non-invasive biomarkers in different medical disciplines, particularly in human reproduction [11].

\subsubsection{Free DNA (CfDNAs)}

The free DNA or CfDNAs are double-stranded DNA molecules moreover [12]. They are present in the bloodstream in the form of fragments of the order of 180 to 360 base pairs. The interest of the study of CfDNA is no longer debated in certain medical disciplines, particularly in oncology [13]. They are used as noninvasive biological markers for cancer pathologies [14] detection or monitoring, the diagnosis of pathologies related to pregnancy $[15,16]$. In the treatment of male infertility, CfDNAs offer innovative new perspectives both from the point of view of diagnosis and prognosis [17]. 


\subsubsection{Free RNA (CfRNAs)}

CfRNAs like CfDNAs also vary according to pathophysiological conditions. They are also used as blood biomarkers for the detection or diagnosis of certain diseases as well as in treatments monitoring. They are detectable in many biological fluids of patients with breast cancer [18], nosopharyngeal carcinoma [19], malignant melanoma [20] and colorectal cancer [21]. The cfRNAs are also used as non-invasive biomarkers in the management of infertility [22].

\subsubsection{MicroRNAs (miRNA)}

MicroRNAs are short strands of non-coding RNA of the order of 19 to 25 nucleotides [23]. MicroRNAs do not code for proteins [24]. Their main and basic role is to block the translation of proteins into the mRNA to which they are attached [25]; they are involved also in various pathologies such as: foamy virus [26], HIV [27], vesicular stomatitis [28], hepatitis C [29], cancer [30].

However, MiRNAs are also important noninvasive biomarkers in human fertility especially for men, diagnosis as well as in the prevention of human abnormalities in general [31].

\subsubsection{Piwi-interacting RNA (PiRNAs)}

The use of circulating nucleic acids as noninvasive biomarkers has been extended to piwi interacting RNA (PiRNA). PiRNAs are a class of small RNAs of the order of 24 to 31 nucleotides [32]. The function of PiRNAs is to block the activity of the mobile elements present in the DNA. They are used as biomarkers because they have been shown to be unregulated in certain cancerous conditions [33], such as: Colorectal cancer [34], prostate cancer [35], and pancreas cancer [36]. They also take part in maintaining the integrity of germinal DNA. Consequently, they constitute important non-invasive biomarkers in infertility management.

\subsubsection{Small interfering RNAs (siRNA)}

The small RNAs are interfering RNAs exact same way as the miRNAs. SiRNAs are able to bind specifically to an mRNA sequence; therefore, they prevent expression by cleaving that RNA. They are present in many biological fluids such as: urine [37], seminal plasma [38] spermatozoa [39] and serum [38]. Several researchers have shown that the level of nucleic acids can be a tool for early diagnosis in certain pathologies.

\subsection{In Human Plasma, Serum, Urine, Seminal Plasma and Sperm}

The detect-ability of CfDNA in many biological fluids makes them real biomarkers of interest, not only for the detection of many diseases but also for the follow-up of certain treatments.

Schwarzenbach et al. have shown that the level of CfDNAs in serum is an early detection tool for colorectal cancer. Indeed, they found a high level of CfDNA (22, 3 to $9.22 \mathrm{ng} / \mathrm{ml}$ ) in the serum of patients with colorectal cancer compared to healthy donors $(5-16 \mathrm{ng} / \mathrm{ml})$ [40]. In the same vein, the team of Schaw has found that there was a difference in CfDNA levels in the plasma of patients with breast cancer and that of healthy donors [41]. In the same way Gormally et al. have shown the utility of CfDNAs in plasma and serum as non-invasive biomarkers for the detection or control of breast and prostate cancer, they found that patients with prostate cancer have a high level of serum CfDNAs compared to healthy donors [42].

CfDNAs were also detected in the urine. Their presence is explained by the transfer of renal blood or directly from cells that have been in contact with this biological fluid [43]. An increase in the amount of CfDNAs was noted in the urine of patients with serious pancreatitis compared to healthy donors [44]. The team of Brygunova showed that smokers' urine had more CfDNAs than non-smokers (9.46 and $9.04 \mathrm{ng} / \mathrm{ml}$ for women, respectively 4.96 and $2.93 \mathrm{ng} / \mathrm{ml}$ ) for men [45].

Salvi et al. have found an increase in the amount of CfDNAs in the urine of patients with acute pancreatitis compared with healthy controls [44].

\section{SEMINAL CFDNAS AS SIGNALING MOLECULES IN CELLULAR COMMUNICATION}

\subsection{Seminal CfDNAs Resulting from the Apoptotic or Necrotic Process}

The exact mechanism by which CfDNAs are released into the bloodstream is not always clear. However, many researchers believe that CfDNAs are produced by apoptotic cells [46]. Others argue that CfDNAs result from the 
necrotic process or even phagocytosis [47]. Thus, it should be remembered that apoptosis remains the main contributor of CfDNAs even if the origin is still uncertain [48]. In view of the fact that Stroun's team has said that living cells can release CfDNAs [49].

\subsection{Free DNA (CfDNAs) and Exosomes}

Exosomes are small particles of the order of 30 to $140 \mathrm{~nm}$. They are membrane-bound and result from multivariate fusion (MVB) with the plasma membrane [50]. Exosomes can be released into various biological fluids such as plasma, saliva and urine [51]. Exosomes are an important source of biomarker for early detection of tumors, monitoring and planning of cancer treatments. Moreover Grange noted some difference in the protein profiles of RNAs and MicroRNAs from cancer cell exosomes [52]. Zhang's team showed that in the case of breast cancer, exosomes derived from stroma contribute to the quiescence of these, cells via the CXCL-12 screening of miRNAs [53].

\subsection{Free DNA (CfDNAs) Detection Information of Genetic and Epigenetic}

The sperm is a mixture of liquids resulting from various secretions from the two testicles, the epididymis, the seminal vesicles, the Cowper glands and the prostate [54]. The epigenetic information contained in seminal CfDNAs which plays an important role in spermatogenesis. It is involved in the reorganization and condensation of the genome of germ cells during maturation. Indeed [40], it reflects the epigenetic aberrations of the testes [55], the problems of male infertility.

\section{SEMINAL FREE DNA (CFDNAS) FOR THE DIAGNOSIS OF MALE INFERTILITY}

The abundance of CfDNAs in sperm is due to significant apoptosis during spermatogenesis. According to the Costa's team, the presence of CfDNAs is associated with sperm parameters [56]. That explains why CfDNAs can be a biomarker for the diagnosis and evaluation of secretory sperm organs.

\subsection{Free DNA (CfDNAs) CfDNA}

CfDNAs are detectable in human sperm. Its concentration in sperm is much higher than in other biological fluids [40]. Its presence and concentration is directly correlated to sperm parameters such as speed, morphology or even mobility [55]. According to $\mathrm{Li}$ et al. the level of CfDNA is higher in the seminal plasma of patients with defective sperm parameters [57]. These observations explain the use of CfDNAs in the search for biological markers of sperm quality.

\subsection{Free RNA (CfRNAs)}

CfRNAs is an excellent biomarker for sperm quality. The team of Steger have detected high levels of Prm1 and Prm2 and mRNA in sperm obtained in patients whose in vitro fertilization (IVF) had failed compared to those whose in vitro fertilization was successful [58]. Bansal et al. have also established a probable correlation between the profile of sperm DNA and male infertility [59].

\subsection{MicroRNAs (miRNA)}

The expression of microRNAs, that are present in sperm, can be a very interesting approach and a valuable aid in routine practice of predicting sperm quality. According to the Salas-Huetos team, human sperm contains a stable population of miRNAs linked to embryogenesis and spermatogenesis [60]. Still Salas-Huetos et al. have shown that MIR-34-P, MIR-132-3P, mir30C-5P and miR-375 play a role in cell cycle progression and sperm differentiation [61].

\subsection{Piwi-interacting RNA (PiRNAs)}

The presence in human spermatozoa, piRNAs represent $11 \%$ of CfRNAs [62]. PiRNAs are used in the evaluation of sperm quality and they offer new perspectives for diagnosis, prognosis and treatments in the management of male infertility [8].

\section{NON-OBSTRUCTIVE AZOOSPERMIA}

Due to a lack of adequate intrinsic gonadotropin stimulation or testicular insufficiency, nonobstructive azoospermia is diagnosed in approximately $10 \%$ of infertile men [63]. According to the Drabovich team, the concentration of CfDNA is much higher in sperm than in other human body fluids, with an average value of $1.34 \mathrm{pg} / \mathrm{ml}$ in normozoospermia and $2.56 \mathrm{pg} / \mathrm{ml}$ cases azoospermia cases [64]. The team of $\mathrm{Li}$ in a recent analysis of the different mRNA and microRNA profiles of patients with non-obstructive azoospermia and patients with 
obstructive azoospermia (OA) found differences in profiles with control (normozoospermia) [65]. Meanwhile, Wang et al. demonstrated differences in seminal plasma microRNA expression patterns, performed studies in patients with non-obstructive azoospermia (NAO) versus fertile men and noted a sharp decrease in expression of seven microRNAs (miR-346-5p, miR-122, Mir $149+-5 p$, miR181a, miR-374b, miR-509 and miR-513a-5p) in the seminal plasma of patients with NOA compared to the control [66]. However, in a study by Gunes's team in patients with azoospermia, they found the additional expression of miR-34c-5p, miR122, miR-146b-5p, miR-181a, 374b Mir, miR509- $5 p$ and 513a-5P which is increased strongly in the case of asthenozoospermia [67]. In the same vein, the team of $\mathrm{Wu}$ analyzed the testicular tissues of NOA patients and found a significant increase in the expression of miR-141, miR-429 and miR-7-1-3p in plasma. Seminal NOA compared to fertile controls [68].

\section{TERATOZOOSPERMIA, ASTHENO- ZOOSPERMIA AND OLIGOZOOS- PERMIA}

Male fertility may be affected by abnormalities such as: reduced mobility (asthenozoospermia), abnormal morphology (Teratozoospermia), nondetectable sperm (azoospermia) or decreased sperm count (oligozoospermia).

\subsection{Teratozoospermia}

Teratozoospermia is characterized by the presence of spermatozoa with an abnormal morphology greater than $85 \%$ in spermatozoa. In the exploration of markers useful to better compensate for male infertility, Herati et al. made a comparison of sperm expression profiles of men teratozoospermia and found a decrease in the expression of SAH-miR-19b-3p, hsa-miR-28$5 p$, SAH-miR-148B and 106B-mir-5P [69]. This clarifies the interest of these miRNAs as biomarkers male infertility management.

\subsection{Asthenozoospermia}

Patients with asthenosozoospermal disease, Safarinejad et al. noted an increase in the expression of SAH-miR548c-5p, SAH-miR548c$5 p$, and SAH-miR-27a, SAH-mi-548b -5p -548d5P [31]. While Abu-Halima and his collaborators noted a dysregulation of a-miR-34b-3p in patients with asthenoszoopermia [32].The same way, an increase in HSA-miR-27a expression has been observed in asthenozoospermic patients [70].

\subsection{Oligozoospermia}

In a study by Wang, in which he compared the expression patterns of miRNAs from normal and oligozoospermic patients, a significantly lower level of mir-34C-5p, Mir 122, miRNA expression was observed. 14BB-5P, miR -181A, miR-374b, miR-509-5p and miR-531a-5P noted by the controls [71]. Wu et al. have found a strong expression of miR-19b and miR -7bis in patients with oligospermia [68]. Bilge Özsait Selçuk found a significant increase in the expression level of miR-21 and miR-22. However, finding a threshold value for the diagnosis and prognosis of male infertility remains a problem.

\section{IDIOPATHIC INFERTILITY AND OTHER FUNCTIONAL SPERM DEFECTS (DNA FRAGMENTATION, ROS, METHYLA- TION, PROTEOMICS, mi-RNA)}

Idiopathic male infertility is defined as the absence of a causal factor in sperm analysis when the sperm has abnormalities such as azoospermia, oligozoospermia, asthenozoospermia or teratozoospermia [31]. It can be affected by other factors such as: DNA fragmentation, oxidative stress, methylation or protein.

\subsection{DNA Fragmentation}

DNA fragmentation is an important factor in the etiology of male infertility [72] or even a good indicator of the potential of conventional sperm parameters [73]. Because sperms with normal sperm parameters can have DNA damage [74]. Das In a study of the etiology of age-related male infertility shows that DNA fragmentation can lead to reduced motility of spermatozoa [75]. Similarly, Twyma-Saint Victor's team in a study published and carried out on three patients suffering from male infertility reveals that the proportion of spermatozoa with fragmentation of the DNA varies between 4.4 and 28 , compared to a percentage of DNA fragmentation of $1.20 \pm 0.95$ between controls [69]. Apart from DNA fragmentation, various conditions such as stress chromatin condensation, methylation can affect men [76].

\subsection{Oxidative STRESS}

Even if a low concentration of ERO is necessary for the critical stages (capacitation, acrosomal 
reaction and fusion between the oocyte and sperm) of fertilization [77]. It turns out that, cellular stress in all its forms, can lead to DNA fragmentation and affect male fertility. According to Twigg seminal ERO levels can lead to sperm injury leading to male infertility. Only the lack of consensus on the physiopathological limits of ERO remains the crucial problem [78].

\subsection{Methylation}

The methylation of DNA modifies the genetic material. It is a causative factor of infertility [79]. The example of the modulating AMPC response element (PAC) gene, which has a high concentration, becomes a negative factor for normal motility and sperm morphology. Arifin's teams have shown that methylation contributes to the increase of mesoderm-specific transcriptase (MEST) in association with abnormal sperm parameters and male infertility [80].

\subsection{Proteomics}

In seminal fluid, sperm accounts for $10 \%$ of the total volume of ejaculation while $90 \%$ is a diverse molecular composition. The specific protein concentration provides a rich source of potential biomarkers in the assessment of male fertility [81]. The team of Mitsumoto observed in infertile men a decrease in the protein (DJ-1-A) involved in the regulation of oxidative stress [82]. Diamandis also found a positive correlation between the seminal concentration of Prostaglandin-D-Synthase (PTGDS) with the mobility and normal morphology of spermatozoa [83]. The proteomic study conducted in the search for biological markers of azoospermia conducted by Bieniek showed that proteins such as, PTGDS, ACRV1, LGALS3BP, ECM1 and TEX101 are seminal biomarkers for the evaluation of male infertility [84].

\section{SEMINAL TECHNICAL APPROACH CFDNAS FROM THE ANIMAL MODEL TO HUMANS}

The development of biomarkers for the diagnosis of male infertility, the provision of assistance for drug development and its application at the human level cannot be possible without having gone through the animal model, including the mouse [85]. The experts in reproductive biology use several animal models. But in this part, we will only talk about the proteomic technology of sperm. The mouse model led to the identification of 52 proteins at the spermatic level [86]. Bleil et al. from the sperm of the boar have identified the surface proteins of the spermatozoa responsible for connecting the spermatozoon to the oocyte [87]. The list of animals used as models is very long. The dog remains the best experimental model for comparative studies in humans because of the similarity of the prostate [88]. The main challenge according to Naughton is the translation of knowledge acquired from its animal models to the male infertility clinic for an improvement of existing treatment, the development of an accurate diagnosis and the formulation of male contraceptives with minimal side effects [46].

\section{CONCLUSION}

The use of nucleic acids as biomarkers of male fertility remains an innovative approach and is extremely promising because it offers new perspectives from a diagnostic as well as prognostic points of view. This is because of the relationship between the level of CfDNA and the presence or absence of spermatozoa. In addition it is a noninvasive procedure and therefore reduces the risks the patient is exposed to.

\section{COMPETING INTERESTS}

Authors have declared that no competing interests exist.

\section{REFERENCES}

1. Swaminathan R, Butt, AN. Circulating nucleic acids in plasma and serum: Recent developments. Ann NY Acad Sci. 2006; 1075(1):1-9.

2. Lichtenstein AV, Melkonyan HS, Tomei LD, Umansky SR. Circulating nucleic acids and apoptosis. Ann NY Acad Sci. 2001; 945(1):239-249.

3. Sirotkin AV, Ovcharenko D, Grossmann R, Lauková M, Mlynček M. Identification of MicroRNAs controlling human ovarian cell steroidogenesis via a genome-scale screen. J cell phy, 2009;219(2):415-420.

4. Hayashi K, de Sousa Lopes SMC, Kaneda $M$, Tang $F$, Hajkova $P$, Lao $K$, et al. MicroRNA biogenesis is required for mouse primordial germ cell development and spermatogenesis. PloS One. 2008; 3(3):1738.

5. Galbiati S, Causarano V, Pinzani P, Francesca S, Orlando C, Smid $M$, et al. Evaluation of a panel of circulating DNA, RNA and protein potential markers for 
pathologies of pregnancy. Clin Chem Lab Med. 2010;48(6):791-794.

6. Traver S, Assou S, Scalici E, Haouzi D, AlEdani T, Belloc S, et al. Cell-free nucleic acids as non-invasive biomarkers of gynecological cancers, ovarian, endometrial and obstetric disorders and fetal aneuploidy. Hum Reprod Update. 2014; 20(6):905-923.

7. Markstrom E, Svensson E, Shao R, Svanberg B, Billig $H$. Survival factors regulating ovarian apoptosis-dependence on follicle differentiation. Reproduction. 2002;123(1):23-30.

8. Boissière $A$, Gala $A$, Ferrières-Hoa $A$, Mullet T, Baillet S, Petiton A, et al. Cellfree and intracellular nucleic acids: New non-invasive biomarkers to explore male infertility. Basic Clin Androl, 2017;27(1):7.

9. Siomi MC, Sato K, Pezic D, Aravin AA. Small RNA-PIWI interaction: The vanguard of genome defense. Nat Exam Mol Cell Bio. 2011;12(4):246.

10. Danko CG, Hah N, Luo X, Martins AL, Core L, Lis JT, et al. Signaling pathways differentially affect RNA polymerase II initiation, pause, and rate of elongation in cells. Mol Cell. 2013;50(2):212-222.

11. Yang $Y, Q u$ A, Liu J, Wang R, Liu Y, Li G, et al. Serum miR-210 contributes to the detection of a tumor, the prediction of the scene and to dynamic surveillance in patients with bladder cancer. PLoS One. 2015;10(8):135-168.

12. Fawzy A, Sweify KM, El-Fayoumy HM, Nofal N. Quantitative analysis of plasmafree DNA and DNA integrity in patients with metastatic prostate cancer using the ALU sequence. J Egypt Natl Canc Inst. 2016; 28(4):235-242.

13. Hickerson RP, Vlassov AV, Wang $Q$, Leake D, Ilves H, Gonzalez-Gonzalez E, et al . Stability study of unmodified siRNA and relevance to clinical use. Oligonucleotides. 2008;18(4):345-354.

14. Brennan CW, Verhaak RG, McKenna A, Campos B, Noushmehr H, Salama SR, et al. The somatic genomic landscape of glioblastoma. Cell. 2013;155(2):462-477.

15. Rowe PJ, Comhaire FH, Hargreave TB, Mahmoud AM. WHO manual for the standardized investigation and diagnosis of the infertile male. Cambridge University Press; 2000.

16. Ewigman BG, Crane JP, Frigoletto FD, LeFevre ML, Bain RP, McNellis D, et al. Effect of prenatal ultrasound screening on perinatal outcome. Taiwan $\mathrm{J}$ Obstet Gynecol. 1993;329(12):821-827.

17. Akers JC, Gonda D, Kim R, Carter BS, Chen CC. Biogenesis of extracellular vesicles (EV): Exosomes, microvesicles, retrovirus-like vesicles, and apoptotic bodies. J Neurooncol. 2013;113(1):1-11.

18. Fernandez-Mercado $\mathrm{M}$, Manterola $\mathrm{L}$, Larrea E, Goicoechea I, Arestin M, Armesto $\mathrm{M}$, et al. The circulating transcriptome as a source of non-invasive cancer biomarkers: Concepts and controversies of non-coding and coding RNA in body fluids. J Cell Mol Med. 2015;19(10):2307-2323

19. Lo YD, Zhang J, Leung TN, Lau TK, Chang AM, Hjelm NM. Rapid clearance of fetal DNA from maternal plasma. Am J Hum Genet. 1999;64(4):218-224.

20. Kopreski MS, Benko FA, Kwak LW, Gocke $\mathrm{CD}$. Detection of tumor messenger RNA in the serum of patients with malignant melanoma. Oncology. 1999;5(8):19611965.

21. Dasí F, Lledó S, García-Granero E, Ripoll $\mathrm{R}$, Marugán $\mathrm{M}$, Tormo $\mathrm{M}$, et al. Real-time quantification in plasma of human telomerase reverse transcriptase (hTERT) mRNA: A simple blood test to monitor disease in cancer patients. Laboratory Investigation. 2001;81(5):767.

22. Brass $A L$, Huang IC, Benita $Y$, John SP, Krishnan MN, Feeley EM, et al. The IFITM proteins mediate cellular resistance to influenza A H1N1 virus, West Nile virus, and dengue virus. Cell. 2009;139(7):12431254.

23. Bartel DP. MicroRNAs: Genomics, biogenesis, mechanism, and function. Cell. 2004;116(2):281-297.

24. Wright EL, Eisenhardt $P R$, Mainzer AK, Ressler ME, Cutri RM, Jarrett T, et al. The wide-field infrared survey explorer (WISE): Mission description and initial on-orbit performance. J Egypt Natl Canc Inst. 2010; 140(6):1868.

25. Ketting RF, Fischer SE, Bernstein E, Sijen $\mathrm{T}$, Hannon GJ, Plasterk RH. Dicer functions in RNA interference and in synthesis of small RNA involved in developmental timing in $C$. elegans. Genes Dev. 2001;15(20):2654-2659.

26. Lecellier $\mathrm{CH}$, Dunoyer $\mathrm{P}$, Arar $\mathrm{K}$, Lehmann-Che J, Eyquem S, Himber $C$, et al. A cellular microRNA mediates antiviral defense in human cells. Science. 2005; 308(5721):557-560. 
27. Levy S, Sutton G, Ng PC, Feuk L, Halpern $A L$, Walenz BP, et al. The diploid genome sequence of an individual human. PLoS One. 2007;5(10):254.

28. Otsuka M, Jing Q, Georgel P, New L, Chen $J$, Mois J, et al. Hypersusceptibility to vesicular stomatitis virus infection in Dicer1-deficient mice is due to impaired miR24 and miR93 expression. Immunity. 2007;27(1):123-134.

29. Pederson EL, Vogel DL. Male gender role conflict and willingness to seek counseling: Testing a mediation model on college-aged men. J Couns Psychol. 2007;54(4):373.

30. Calin GA, Liu CG, Ferracin M, Hylop T, Spizzo R, Sevignani C, et al. Ultraconserved regions encoding ncRNAs are altered in human leukemias and carcinomas. Cancer Cell. 2007;12(3):215229.

31. Abu-halima $M$, Backes $C$, Leidinger $P$, Keller A, Lubbad AM, Hammadeh M, et al. MicroRNA expression profiles in human testicular tissues of infertile men with different histopathologic patterns. Fertil Steril. 2014;101(1):78-86.

32. Aravin AA, Sachidanandam R, Girad A Fejes-Toth K, Hannon GJ. Developmentally regulated piRNA clusters implicate MILI in transposon control. Science. 2007;316(5825):744-47.

33. Mustoe AM, Brooks CL, Al-hashimi HM. Hierarchy of RNA functional dynamics. Annu Rev Biochem. 2014;83(9):441-466.

34. Spindler KLG, Pallisgaard N, Vogelius I, Jakobsen A. Quantitative cell free DNA, KRAS and BRAF mutations in plasma from patients with metastatic colorectal cancer during treatment with cetuximab and irinotecan. Int J Cancer. 2012;0564

35. Wyatt AW, Azad AA, Volik SV, Annala M, Beja K, McConeghy B, et al. Genomic alterations in cell-free DNA and enzalutamide resistance in castrationresistant prostate cancer. JAMA Oncol. 2016;212(159):16-27.

36. Giacona MB, Ruben GC, Iczkowski KA, Roos TB, Porter DM, Sorenson GD. Cellfree DNA in human blood plasma: Length measurements in patients with pancreatic cancer and healthy controls. Pancreas. 1998;17(1):89-97.

37. Iversen F, Yang C, Dagnaes-Hansen F, Schaffert DH, Kjems J, Gao S. Optimized siRNA-PEG conjugates for extended blood circulation and reduced urine excretion in mice. Theranostics, 2013;3(3):201.
38. Liu L, Liu C, Lou F, Zhang G, Wang X, Fan $Y$, et al. Activation of telomerase by seminal plasma in malignant and normal cervical epithelial cells. J Pathol. 2011; 225(2):203-211.

39. Tsang J, Zhu J, Van Oudenaarden A. MicroRNA-mediated feedback and feed forward loops are recurrent network motifs in mammals. J Cell Mol Med. 2007; 26(5):753-767.

40. Schwarzenbach H, Hoon DS, Pantel K. Cell-free nucleic acids as biomarkers in cancer patients. Nat Rev Cancer. 2011; 11(6):426.

41. Shaw BJ, Al-Bairuty G, Handy RD. Effects of waterborne copper nanoparticles and copper sulphate on rainbow trout, (Oncorhynchus mykiss): Environ Toxicol Chem. 2012;116:90-101.

42. Gormally E, Caboux E, Vineis $P$, Hainaut $P$. Circulating free DNA in plasma or serum as biomarker of carcinogenesis: Practical aspects and biological significance. Clin Chem. 2007;635(2):105-117.

43. Brygunova OE, Lakaktionov PP. Extracellular nucleic acids in urine: sources, structure, diagnostic potential. Acta Naturae. 2015;7(3):26.

44. Salvi S, Gurioli G, De Giorgi U, Conteduca V, Tedaldi G, Calistri D, et al. Cell-free DNA as a diagnostic marker for cancer: Current insights. Onco Targets. 2016; 96(5):49.

45. Hui CYY, Tan WC, Tan EL, Tan LK. Repeated failed non-invasive prenatal testing in a woman with immune thrombocytopenia and antiphospholipid syndrome: Lessons learnt. BMJ Case Reports. 2016;20(1):6.

46. Jung K, Fleischhacker M, Rabien A. Cellfree DNA in the blood as a solid tumor biomarker-A critical appraisal of the literature. Clin Chim Acta. 2010;411:161124.

47. Breitbach S, Tug S, Simon P. Circulating cell-free DNA. Genes Basel. 2012;429(57): 65-86.

48. Stroun $M$, Maurice $P$, Vasiooukhin $V$, Lyautey J, Lederrey C, Lefort F, et al. The origin and mechanism of circulating DNA. Ann N Y Acad Sci. 2000;906(197):161168.

49. Milardi D, Grande G, Vincenzoni F, Castagonla M, Marana R. Proteomics of human seminal plasma: Identification of biomarker candidates for fertility and 
infertility and the evolution of technology. Mol Reprod Dev. 2013;805(456):350-357.

50. Boissonnas $\mathrm{CC}$, Jouannet $\mathrm{P}$, Jammes $\mathrm{H}$. Epigenetic disorders and male subfertility. Fertil Steri. 2013;99(36):24-31.

51. Inhorn MC, Patrizio P. Infertility around the globe: New thinking on gender, reproductive technologies and global movements in the $21^{\text {st }}$ century. Hum Reprod Update. 2015;214(41):14-26.

52. Paker TM, Osternig LR, Lee HJ, VanDonkelaar P, Chou LS. The effect of divided attention on gait stability following concussion. Clin Biomech. 2005;208(43): 89-395.

53. Zhang W, Xia W, Lv Z, Xin Y, Ni C, Yang L. Liquid biopsy for cancer: Circulating tumor cells, circulating free DNA or exosomes? Cellular Phys Bioch. 2017; 41(2):755-768.

54. Assou S, Al-Edani T, Haouzi D, Philippe N, Lecellier $\mathrm{CH}$, Piquemal $\mathrm{D}$, et al. MicroRNAs: New candidates for the regulation of the human cumulus-oocyte complex. Hum Reprod. 2013;28(113):3849.

55. Singh RP, Shafeeque CM, Sharma SK, Singh R, Mohan J, Sastri KVH, et al. Sperm transcriptome profiling by microarray analysis. Genome. 2015;59(3):18596.

56. Costa F, Barbisan F, Assmann CE, Araujo NKF, de Oliveira AR, Signori GP, et al. Seminal cell-free DNA levels measured by PicoGreen fluorochrome are associated with sperm fertility criteria. Zygote. 2017; 25(21):11-19.

57. Li HG, Huang SY, Zhou H, Liao AH, Xiong CL. Quick recovery and characterization of cell-free DNA in seminal plasma of normozoospermia and azoospermia: implications for non-invasive genetic utilities. Asian J Androl. 2009;11(6):703.

58. Steger K, Fink L, Failing K, Bohle RM, Kliesch S, Weidner W, et al. Decreased protamine-1 transcript levels in testes from infertile men. Mol Hum Repro. 2003;9(6): 331-36.

59. Bansal SK, Gupta N, Sankhwar SN, Rajender S. Differential genes expression between fertile and infertile spermatozoa revealed by transcriptome analysis. PloS One. 2015;10(5):e0127007.

60. Salas-Huetos A, Blanco J. Vidal F, Mercader JM, Garrido N, Anton E. New perspectives on the expression profile and function of ribonucleic acid in human micro-spermatozoa. Fertil Steril. 2014; 102(1):213-22.

61. Salas-Huetos A, Blanco J, Vidal F, Godo A, Grossmann M, Pons MC, Anton E. Spermatozoa in patients with seminal alterations have a differential microribonucleic acid profile. Fertil Steril. 2015; 104(3):591-601.

62. Gonzalez JM. Piwi, a nuclear argonaute / piwi protein, is a key regulator of the testicular stem cell niche in Drosophila. Yale University; 2014.

63. Kumar R. Medical management of nonobstructive azoospermia. Clinics. 2013;68: 75-79.

64. Drabovich AP, Sara $P$, Järvi $K$, Diamandis EP. Seminal plasma as a diagnostic fluid for disorders of the male reproductive system. Nat Rev Urol. 2014;11(5):278.

65. Li Z, Zheng Z, RuanJ, Zhuang X, Tzeng CM. Integrated miRNA analysis and mRNA profiling in patients with severe oligozoospermia reveals miR-34c-3p expression PLCXD3 regulates negatively. Oncotarget. 2016;7(33):52781.

66. Wang C, Yang C, Chen X, Yao B, Yang C, Zhu C, et al. Modified microRNA profile of seminal plasma in the molecular diagnosis of male infertility. Clin Chem. 2011;57(12): 1722-31.

67. Gunes S, Arslan MA, Hekim GNT, Asques $R$. The role of epigenetics in idiopathic male infertility. J Repro Ass Gene. 2016; 33(5):553-69.

68. Wu Y, Liang $\mathrm{D}$, Wang $\mathrm{Y}$, Bai $\mathrm{N}$, Tang $\mathrm{W}$, Bao $S$, et al. Correction of a genetic disease in mouse via use of CRISPRCas9. Cell Stem Cell. 2013;13(6):65962.

69. Twyma-Saint Victor C, Rech AJ, Maity A, Regan R, Pauken KE, Stelekati E, et al. Radiation and dual checkpoint blockade activate non-redundant immune mechanisms in cancer. Nature. 2015; 520(7547):373.

70. Poongotha JENS, Gopenath TS, Manoyaki SW. Genetics of human male infertility. Singapore Med J. 2009;50(4):336-347.

71. Wang C, Yang C, Chen, X, Yao B, Yang C, Zhu $C$, et al. Altered profile of seminal plasma microRNAs in the molecular diagnosis of male infertility. Clin Chem; 2011.

72. Agarwal A, Said TM. Role of sperm chromatin abnormalities and DNA damage in male infertility. Hum Reprod Update. 2003;9(4):331-45. 
73. Skinner $M$, Sanchorawala $V$, Seldin DC, Dember LM, Falk RH, Berk JL, et al. Highdose melphalan and autologous stem-cell transplantation in patients with $A L$ amyloidosis: An 8-year study. Ann Intern Med. 2004;140(2):85-93.

74. Avendano C, Franchi A, Taylor S, Morshedi M, Bocca S, Oehninger S. Fragmentation of DNA in morphologically normal human spermatozoa. Fertil Steril. 2009;91(4):1077-84.

75. Alminana-Brines $C$. Snooping on a private conversation between the oviduct and gametes/embryos. Mol Reprod Dev. 2015; 12(3):366-74.

76. Aitken RJ, Koppers AJ. Apoptosis and DNA damage in human spermatozoa. Asian J Androl. 2011;13(1):36.

77. Twigg JP, Irvine DS. Aitken RJ. Oxidative damage to DNA in human spermatozoa does not preclude pronucleus formation at intracytoplasmic sperm injection. Hum Reprod. 1998;13(7):1864-71.

78. Handel AE, Ebers GC, Ramagopalan SV. Epigenetics: Molecular mechanisms and implications for disease. Trends Mol Med. 2010;16(1):7-16.

79. Arifin D, Aston VJ, Liang X. CoFe2O4 on a porous $\mathrm{Al} 2 \mathrm{O} 3$ nanostructure for solar thermochemical $\mathrm{CO} 2$ splitting. J Cell Mol Med. 2012;5(11):9438-43.

80. Pilch B, Mann M. Large-scale and highconfidence proteomic analysis of human seminal plasma. Genome Biol. 2006;7(5): R40.

81. Kamath SD, Rahman AMA, Komoda T. Impact of heat processing on the detection of the major shellfish allergen tropomyosin in crustaceans and molluscs using specific monoclonal antibodies. Mol Nutr Food Res. 2013;141(4):4031-39.

82. Mitsumoto A. Nakagawa $Y . D J-1$ is an indicator for endogenous reactive oxygen species elicited by endotoxin. Free Radic Res. 2001;35(6):885-893.

83. Diamandis EP, Arnett WP, Foussias G. Seminal plasma biochemical markers and their association with semen analysis findings. Int J Urol. 1999;53(3):596-603.

84. Bieniek, JM, Drabovich AP, Lo KC. Seminal biomarkers for the evaluation of male infertility. Asian J Androl. 2016;18(3): 426.

85. Ong KT, Perdu J, De Backer J. Effect of celiprolol on prevention of cardiovascular events in vascular Ehlers-Danlos syndrome: A prospective randomised, open, blinded-endpoints trial. The Lancet. 2010;376:1476-84.

86. De Jong M, Maina T. Of mice and humans: Are they the same? - Implications in cancer translational research. J Nucl Med. 2010;51:501-04.

87. Bleil Jeffrey $D$, Wassarman Paul $M$. Mammalian sperm-egg interaction: identification of a glycoprotein in mouse egg zonae pellucidae possessing receptor activity for sperm. Cell. 1980;20:873-82.

88. Naughton Cathy K, Nangia Ajay K. Agarwal Ashok. Varicocele and male infertility: Part II: Pathophysiology of varicoceles in male infertility. Hum Reprod Update. 2001;7:473-81.

(c) 2018 Mbaye et al.; This is an Open Access article distributed under the terms of the Creative Commons Attribution License (http://creativecommons.org/licenses/by/4.0), which permits unrestricted use, distribution, and reproduction in any medium, provided the original work is properly cited.

Peer-review history:

The peer review history for this paper can be accessed here: http://www.sdiarticle3.com/review-history/46952 